\title{
Comparative Evaluation of Sweet Orange Waste Meals and Wheat Offal as Fibre Sources in Growing Rabbits Diets
}

\author{
Okokon. O. Effiong ${ }^{1}$, G. S. I. Wogar ${ }^{1} \&$ Donald. E. Umana ${ }^{1}$ \\ ${ }^{1}$ University of Calabar, Calabar, Nigeria \\ Correspondence: Okokon O. Effiong, University of Calabar, Calabar, Nigeria. Tel: 234-080-3660-2048. E-mail: \\ okokoneffiong2010@yahoo.com
}

Received: October 10, 2012 Accepted: November 26, 2012 Online Published: February 17, 2013

doi:10.5539/jas.v5n3p164

URL: http://dx.doi.org/10.5539/jas.v5n3p164

\begin{abstract}
The study was designed to evaluate the proximate composition and nutritional potential of orange waste meals in rabbits' diet. The orange wastes (endocarp, mesocarp and whole) meals were gathered from fruit juice processing factory at Export Processing Zone (EPZ) in Calabar Municipality, sundried and milled. Based on the crude protein content, four experimental diets were formulated; Diet one contained wheat offal, serving as control, while Diets 2 to 4 had wheat offal in the control diet replaced by the orange endocarp, mesocarp and the whole orange waste meal, respectively. Forty rabbits of mixed sexes, used for the experiment were weighed and randomly distributed into four 4 groups of Ten rabbits each. Each group was randomly assigned to one of the four (4) experimental diets and fed for 10 weeks. The result showed that the inclusion of orange wastes meal in rabbits diets significantly $(\mathrm{P}<$ $0.05)$ improved the average daily weight gain with the highest ( $13.99 \mathrm{~g} /$ day) in group fed diet 4 , average daily feed intake, feed conversion ratio and cost per $\mathrm{kg}$ weight gain. Cost of producing a $\mathrm{kg}$ of feed and cost of feed consumed by rabbits were significantly reduced. The orange waste meal did not significantly influenced the carcass and internal organs of the animals. It was concluded that, the orange wastes meal could replace wheat offal in growing rabbits' diet.
\end{abstract}

Keywords: orange mesocarp and endocarp, growing rabbit, fibre

\section{Introduction}

The past few years have witnessed a rapid growth in the population of developing Countries, including Nigeria with the resultant increase in the demand for protein of animal origin. Meanwhile, increasing the production of the animal protein at the reasonable cost to enhance the diet quality of the populace has been part of the National Agricultural policy and the use of micro-livestock and short cycle animals have been suggested (Cheeke, 1986).

Rabbits play important role in the supply of animal protein to the Nigerian populace (Amaefule, Ihekwemere, \& Nkwaokor, 2005). They are efficient converters of feed to meat and can utilize up to $30 \%$ of crude fibre as against $10 \%$ by most poultry species (Egbo, Doma, \& Landaks, 2001). However, rabbit production has not received the desired attention in the tropics. Productivity is usually $50 \%$ or less of what is typical in the temperate countries (Cheeke, 1986). The high cost of formulated concentrates and pelletized feeds, compounded from the conventional ingredients, including; maize and soybean militates against increased rabbit production. (Agunbiade, Osilalu, \& Adeyemi, 2001). More so, the use of acceptable human food for feeding animals is unjustified (Olupong \& Balogun, 2005).

Thus supplementation with under-utilized unconventional feedstuff is considered. One of such is grain by-products including; maize offal, rice bran, corn cob, wheat bran and offal that serve as fibre sources (Oluokun \& Olalokun, 1999).

Unfortunately, most of the fibre sources are becoming scarce and expensive. There is need therefore to search for other alternatives. One of the sources considered are the orange wastes meal. The orange wastes meals which are residues left after juice extractions include; the peel, mesocarp (the white portion) and the endocarp (pulp). The fruits wastes which are abundant in juice-canning industries in Nigeria have no direct human use and can be considered as wastes on Nigerian farms. Sweet orange wastes are also usually noticed on streets and along major roads in Nigeria, because government and orange retailers have no strategic disposal programme, thus becoming an environmental problem. Rather than discarding the orange wastes, they can be sun-dried and then milled in 
grinding machine to fine particle to obtain the orange waste meal which can be included in livestock diets (Oluremi, Ngi, \& Andrew, 2007).

Sweet orange is grown in more than 125 countries and its worldwide production has increased from 24 million tonnes in 1961 to 71 million tonnes in 1990 (Wardowski, Nagy, \& Grierson, 1986). The reported chemical composition of the orange wastes are; $91.5 \% \mathrm{DM}, 10 \% \mathrm{CP}, 9.35 \% \mathrm{CF}, 1.25 \mathrm{EE}, 5.25$ Ash and $65 \%$ Nitrogen free extract.

Sweet orange fruit rind (peel) meal has been observed to be a source of calorie and protein comparable with maize (Oluremi, Ojighen, \& Ejembi, 2006). The peel contains oil sacs and the oil is composed of $91-94 \%$ d-limonene and 2.0-2.1\% B-myrcene as a minor constituent. Polymetholated flavones are also a class of compound found in citrus peel and produce no negative side effects in the animals fed the polymetholated flavones containing diets.

The objective of this research was to explore the nutritional potential of orange wastes meal as an alternative fibre sources in growing rabbit diets.

\section{Materials and Methods}

\subsection{Processing of the Experimental Material}

The orange wastes meal (residue after extracting juice) were gathered from fruit juice processing factory at Export Processing Zone (EPZ) in Calabar Municipality and divided into two batches: the wastes meal in the first group were sundried, while those in the second group were separated into mesocarp (white outer part) and the endocarp (pulp) and sundried. The sundried orange waste meal (mesocarp, endocarp and the whole), were individually milled and stored in air tight container, prior to chemical analyses and feed formulation.

\subsection{Proximate Analysis}

Proximate analyses of the milled orange by-products and wheat offal were carried out to determine the proximate composition. The percentage crude protein, crude fibre, ether extract, total ash and nitrogen free extract were determined according to the methods of AOAC (1995).

\subsection{Preparation of Experimental Diets}

Four experimental diets were formulated as follows. Diet 1 was the control, having wheat offal as its fibre source. Diets 2, 3, and 4 had the wheat offal in the control diet replaced with the orange endocarp meal (OEM), orange mesocarp meal (OMM) and combination of the endocarp and mesocarp, (whole orange waste meal), respectively as their fibre sources. The compositions of the diets are shown in Table 2.

\subsection{Experimental Animals and Management}

Forty (40) unsexed, cross breed (American Chincilla x Newzealand white, weaned rabbits, aged five (5) weeks old were used for the experiment. They were individually weighed and distributed into four (4) groups of ten (10) rabbits, each on weight equalization basis. Each group was randomly assigned to one of the four diets described earlier, in a completely randomized design. They were individually housed in a double tier hutch, made of wood and wire mesh, measuring $60 \mathrm{~cm} \times 60 \mathrm{~cm}$. The hutches were placed in an enclosed building with proper ventilation. Feed and water were offered in a concrete crocks.

The feed intake of each rabbit, on treatment basis was taken daily by subtracting the left over from the initial quantity offered. Individual feed intakes for the five rabbits were sum up to obtain the average daily feed intake in each treatment.

Weight of rabbits were taken weekly on treatment basis to obtain the average weekly weight gain.

Records of average feed intake and the weight gain were used to compute the feed conversion ratio. Economics of feeding the orange wastes meal to rabbits was evaluated. To calculate the cost per kilogram of feed, the price of each ingredient was taken and used to multiply the quantity $(\mathrm{kg})$ of ingredients used in compounding each diet. The cost of feed consumed was calculated by multiplying cost per kilogram of feed by the kilogram of feed consumed by rabbits on each treatment. The cost per kilogram of weight gain was obtained from the ratio of the cost of feed consumed and the weight gain measured in kilogram.

\subsection{Carcass and Internal Organs Evaluation}

At the end of feeding trial, four rabbits per treatment were randomly selected from each treatment for carcass evaluation. They were fasted over night and weighed prior to slaughtering. The animals were thoroughly bled by hanging them head down through the hind leg on a nail, then the carcass were disserted and eviscerated. The weight of internal organs were taken and recorded. The carcasses were chilled in a freezer for twenty four hours 
and re-weighed (after thawing) to determine the cold carcass weight and then dissembled into wholesale cut and each primal part was weighed.

Table 2. Composition of experimental diet

\begin{tabular}{lcccc}
\hline \multirow{2}{*}{ Ingredients } & \multicolumn{4}{c}{ Different fibre sources } \\
\cline { 2 - 5 } & Diet 1 & Diet 2 & Diet 3 & Diet 4 \\
\hline Maize & 47.8 & 47.78 & 47.8 & 47.8 \\
SBM & 10.7 & 10.7 & 10.7 & 10.7 \\
PKC & 10.0 & 10.00 & 10.0 & 10.0 \\
Wheat offal & 30.0 & - & - & - \\
Mesocarp meal & - & 30.0 & - & - \\
Endocarp meal & - & - & 30.0 & - \\
Whole orange waste & - & - & - & 30.0 \\
*Vitamin/min. premix & 0.5 & 0.5 & 0.5 & 0.5 \\
Lysine & 0.3 & 0.3 & 0.3 & 0.3 \\
Methionine & 0.2 & 0.2 & 0.2 & 0.2 \\
Salt & 0.5 & 0.5 & 0.5 & 0.5 \\
Total & $\mathbf{1 0 0 . 0 0}$ & $\mathbf{1 0 0 . 0 0}$ & $\mathbf{1 0 0 . 0 0}$ & $\mathbf{1 0 0 . 0 0}$ \\
\hline Calculated analysis & & & & \\
Crude protein (\%) & 16.00 & 13.02 & 12.42 & 12.72 \\
Metabolisable energy (Kcal/kg) & 2,685 & 2682.25 & 2766.22 & 2724.45 \\
Crude fibre (\%) & 5.61 & 6.21 & 7.71 & 6.81 \\
Determined analysis & & & & \\
Crude protein (\%) & 15.86 & 13.69 & 13.02 & 12.98 \\
Metabolisable energy (Kcal/kg) & 2697.02 & 2688.68 & 2760.34 & 2715.33 \\
Crude fibre (\%) & 6.70 & 7.23 & 7.89 & 7.02 \\
\hline
\end{tabular}

*vitamin-mineral premix provide per kg of diet: vit A. 13,340 iu; vit. D3 2680 iu; vit E. 10 iu, vit K, 2.68 mg; calcium panthothenate, $10.68 \mathrm{mg}$; vit B12, $0.022 \mathrm{mg}$; folic acid, $0.668 \mathrm{mg}$; choline chloride, $400 \mathrm{mg}$; chlorotetracycline, $26.68 \mathrm{mg}$; manganese, $133.34 \mathrm{mg}$; iron, $66.68 \mathrm{mg}$; zinc, $53.34 \mathrm{mg}$; copper, $3.2 \mathrm{mg}$, iodine, $1.86 \mathrm{mg}$; cobalt, $0.268 \mathrm{mg}$, selenium, $0.108 \mathrm{mg}$.

\subsection{Data Analysis}

The data collected were subjected to one way analysis of variance (ANOVA) and significant means separated using Duncan's new multiple range test outlined by Obi (1990).

\section{Results}

\subsection{Proximate Composition}

The result of the proximate composition of the different sections of the orange wastes meal is presented in Table 1 .

Table 1. Proximate compositions of different sections of orange (\% Dry matter)

\begin{tabular}{lccc}
\hline Compositions (\%) & Peel meal & Mesocarp meal & Endocarp meal \\
\hline Crude Protein & $3.50^{\mathrm{c}}$ & $5.25^{\mathrm{b}}$ & $6.56^{\mathrm{a}}$ \\
Crude Fibre & $15.00^{\mathrm{a}}$ & $15.50^{\mathrm{a}}$ & $10.70^{\mathrm{b}}$ \\
Ether Extract & $2.25^{\mathrm{a}}$ & $0.75^{\mathrm{b}}$ & $0.75^{\mathrm{b}}$ \\
Ash & $3.00^{\mathrm{a}}$ & $1.00^{\mathrm{b}}$ & $3.00^{\mathrm{a}}$ \\
Nitrogen Free Extract & $77.5^{\mathrm{a}}$ & $73.99^{\mathrm{b}}$ & $74.99^{\mathrm{b}}$ \\
Dry matter & 96.25 & 96.49 & 96.00 \\
\hline
\end{tabular}

Values are means of triplicate determination.

Means in the same row with unlike superscripts differ $(\mathrm{P}<0.05)$. 
They varied significantly $(\mathrm{P}<0.05)$ in their proximate composition. The crude protein $(\mathrm{CP})$ value was highest $(6.56 \%)$ in the endocarp meal and lowest in the orange peel meal (3.5\%). The Crude fibre (CF) values ranged from $15.5 \%$ in orange mesocarp meal (OMM) to $10.7 \%$ in the orange endocarp meal (OEM). The CF content of the orange peel meal (OPM) and OEM were however statistically similar to each other. The ether extract, ash and nitrogen free extract values were highest in the $\operatorname{OPM}(2.25,3$, and $77.5 \%$, respectively). OMM recorded the least value $(1.0 \%)$ for ash, while OMM and OEM recorded the same values for ether extract.

\subsection{Rabbits Performance}

Data for the performance of rabbits fed diet experimental diets are presented in Table 3.

Table 3. Performance of rabbit fed diets containing different fibre sources

\begin{tabular}{lccccc}
\hline & \multicolumn{5}{c}{ Different fibre sources } \\
\cline { 2 - 6 } Parameters & DIET 1 & DIET 2 & DIET 3 & DIET 4 & \pm SEM \\
\hline Initial weight/rabbit(g) & 686.67 & 681.66 & 676.67 & 676.67 & \pm 1.02 \\
Final weight/rabbit(g) & 1075.00 & 1403.33 & 1369.95 & 1460.00 & \pm 6.10 \\
Weight gain/rabbit(g) & $388.33^{\mathrm{b}}$ & $721.67^{\mathrm{a}}$ & $693.28^{\mathrm{a}}$ & $783.33^{\mathrm{a}}$ & \pm 6.18 \\
Average daily weight gain/rabbit(g) & $6.93^{\mathrm{b}}$ & $12.89^{\mathrm{a}}$ & $12.38^{\mathrm{a}}$ & $13.99^{\mathrm{a}}$ & \pm 0.83 \\
Average daily feed intake/rabbit(g) & $30.47^{\mathrm{c}}$ & $46.70^{\mathrm{b}}$ & $50.59^{\mathrm{b}}$ & $58.68^{\mathrm{a}}$ & \pm 1.60 \\
Feed conversion ratio (FCR) & $4.40^{\mathrm{a}}$ & $3.62^{\mathrm{b}}$ & $4.08^{\mathrm{b}}$ & $4.19^{\mathrm{a}}$ & \pm 0.29 \\
\hline
\end{tabular}

Means with different superscript on the same row are significantly different $(\mathrm{P}<0.05)$.

SEM: standard error of mean

Rabbits fed the orange waste meal diets recorded significant $(\mathrm{P}<0.05)$ higher feed intake than those on control diet. Rabbits on test diet 4 (whole orange waste meal) had the highest daily feed intake of $58.68 \mathrm{~g}$ followed by those on test diet $3(50.59 \mathrm{~g})$.

Mean daily weight gain increased significantly $(\mathrm{P}<0.05)$ in rabbit fed diets containing orange waste meal relative to those fed the control diet containing wheat offal.

Feed conversion ratio $(\mathrm{FCR})$ differ significantly $(\mathrm{P}<0.05)$ among various treatment groups. Rabbits fed Diet 2 had a superior FCR compare with those on diets 1, 3, and 4. FCR values for rabbits on diets 3 and 4 were however superior to those on control diet.

\subsection{Carcass and Internal Organs Evaluation}

The replacement of wheat offal with orange pulp meal in the rabbits' ration had no significant influence $(\mathrm{P}>0.05)$ on carcass of primal cut parts, and internal organs of the rabbits as shown in Table 4 .

Table 4. Economics of feeding different fibre sources to growing rabbits

\begin{tabular}{lccccc}
\hline & \multicolumn{5}{c}{ Different fibre sources } \\
\cline { 2 - 6 } Parameters & DIET 1 & DIET 2 & DIET 3 & DIET 4 & \pm SEM \\
\hline $\begin{array}{l}\text { Cost/kg of feed } \\
\text { as formulated (C\$) }\end{array}$ & $0.37^{\mathrm{a}}$ & $0.31^{\mathrm{b}}$ & $0.31^{\mathrm{b}}$ & $0.31^{\mathrm{b}}$ & \pm 0.09 \\
$\begin{array}{l}\text { Cost of feed } \\
\text { consumed (C\$) }\end{array}$ & $0.78^{\mathrm{d}}$ & $1.00^{\mathrm{c}}$ & $1.09^{\mathrm{b}}$ & $1.25^{\mathrm{a}}$ & \pm 0.23 \\
$\begin{array}{l}\text { Cost } / \mathrm{kg} \text { of } \\
\text { weight gain }(\mathrm{C} \$)\end{array}$ & $2.02^{\mathrm{a}}$ & $1.38^{\mathrm{c}}$ & $1.38^{\mathrm{b}}$ & $1.60^{\mathrm{b}}$ & \pm 0.29 \\
\hline
\end{tabular}

Means with different superscript on the same row are significantly different $(\mathrm{P}<0.05)$.

SEM: standard error of mean. 


\subsection{Economic Performance}

Economics of feeding the orange wastes meal to rabbits are as presented in Table 4.

Cost of producing a kilogram of feed was significantly $(\mathrm{P}<0.05)$ reduced with the inclusion of orange wastes meal in the diets of rabbit. The cost was reduced from $\mathrm{C} \$ 0.37$ in diet containing wheat offal to $\mathrm{C} \$ 0.31$ each for diets containing endocarp, mesocarp and the whole orange wastes meal.

Costs of feed consumed were significantly higher for treatment diets than the control group. Cost of feed per kilogram weight gain was significantly lower $(\mathrm{P}<0.05)$ for orange waste meal diets compared with rabbits on control diet.

The cost of feed per kilogram weight gain for rabbits on control diet was higher relative to those on orange waste meal diets.

\section{Discussion}

The CP in the peel was lower than the $7.44 \%$ and $10.96 \%$ reported by Oluremi et al. (2006) and Oke, Adeyemi, Oke, and Akinpelu (2007) for sweet orange. The CP value of the orange wastes meal for this study were also lower than $9.25 \%$ CP in maize (Oke et al., 2007), $15.50 \%$ CP in maize processing waste (Udedibie, Anyaegbu, Onychekwu, \& Egbuokporo, 2004) and $9.70 \% \mathrm{CP}$ in sorghum, but higher than $2.3 \% \mathrm{CP}$ in cassava root meal (Tuleun, 2005). The CF composition of the entire orange wastes meal was comparatively higher than $2.2 \% \mathrm{CF}$ reported for maize (Akinmutimi \& Ugwu, 2007). The values obtain from this study were in agreement with the range (13.66-14.99\%) reported for some citrus fruit varieties (Oluremi et al., 2007). The dietary implication of a high crude fibre as in OPM is that it may limit its maize replacement value in the diets for monogastric animals, most especially poultry and pigs because of their low fibre utilization efficiency. Higher values for the NFE observed among the orange by-products shows that they are potentially high in energy content.

The highest average daily feed observed in Diet 4, showed that rabbits in this group had more preference, may be due to the palatability of the diet. Adejinmi, Anyaegbu, Onychekwu, and Egbuokporo (2007) observed that the quantity of feed intake in rabbits is dependent to a large extent on the palatability of the feed, the consistency and in the crude fibre content of the feed. Dairo (2005) reported that palatability of feed has an increasing effect on feed intake, and nutrient availability and subsequently, the appetite, thereby giving a higher feed intake.

Olorunsonya, Ayoola, Fayeye, Olagunju, and Olorunsanya (2007) reported an average feed intake range of 39.83-49.03 $\mathrm{g}$, which are similar to the findings of this experiment.

The low daily weight gain by rabbits fed control diet $(6.93 \mathrm{~g})$ could be linked to the decrease in feed intake, which consequently prevented the intake of other nutrients required for growth (Adejinmi et al., 2007). Omage, Onimisi, and Agunbiade (2007) and Aderinola, Ojebiyi, Rafiu, Akinbele, and Adepoju (2008) reported average daily body weight range of $5.23 \mathrm{~g}$ and $13.23 \mathrm{~g}, 15.31 \mathrm{~g}$ and $18.82 \mathrm{~g}$ and $12.00 \mathrm{~g}$ and $18.80 \mathrm{~g}$ for growing rabbits fed ripe plantain peel, Centrosema pubescens and cocoa pod husk based diet, respectively. The reports of these authors agree with the findings of this experiment.

Improved FCR values for rabbits fed orange pulp meal diets show that diets were efficiently utilized and that the feeds were effectively converted to meat. Value obtained in this experiment were however lower than the range (2.18-2.64) reported by Abubakar, Doma, Kalla, Ngele, and Augustine (2006) for rabbits fed diet containing malted or unmalted sorghum.

Non significant effect of orange waste meal diets on rabbits' carcass and internal organs imply that the waste meal did not contain any substances detrimental to the animal.

The cost per kilogram of meat produced was reduced by substituting orange waste meal for wheat offal in the ration.

\section{Conclusion}

From the result of this study, it was concluded that the orange waste meals (mesocarp, endocarp or whole) could economically replace wheat offal in the growing rabbits' ration without adverse effect on performance.

\section{References}

Abubakar, M., Doma, U. D., Kalla, D. J. U., Ngele, M. B., \& Augustine, C. L. D. (2006). Effects of dietary replacement of maize with malted or unmalted sorghum on the performance of weaner rabbits. Livestock Research for Rural Development, 18(5), 1-8. Retrieved from www.lrrd.org/lrrd7/3/9.html

Adejimi, O. O., Hamzat, R. A., \& Fapohunda, J. B. (2007). Performance and nutrient digestibility of rabbits fed fermented and unfermented cocoa pod husk. Nigerian Journal of Animal Production, 34(1), 63-68. 
Aderinola, O. A., Ojebiyi, O. O., Rafiu, T. A., Akinbele, J. A., \& Adepoju, L. O. (2008). Performance evaluation of growing rabbit fed diets containing varying inclusion levels of Centrosema pubescens or calapogonium mucunoides in the savannah zone of Nigeria (pp. 525-528). $9^{\text {th }}$ World Rabbit Congress. Verona - Italy.

Agunbiade, J. B., Osilalu, A. A., \& Adeyemi, O. A. (2001). Performance response of growing rabbits fed different sources and levels of dietary fibre. Tropical Journal of Animal Science, 4(1), 77-84.

Akinmutimi, E. O, \& Ugwu, S. O. C. (2007). Performance of Laying Hen fed varying Dietary Levels of Bambara (Voandzeia Subterrenea Thouars) Offals. International Journal of Poultry Science, 6(3), 223-226. http://dx.doi.org/10.3923/ijps.2007.223.226

Amaefule, K. U., Iheukwemere, F. C., \& Nwaokor, C. C. (2005). The growth performance and carcass characteristics of rabbits fed graded dietary levels of boiled pigeon pea seed (Cajanus cajan). Livestock Resource for Rural Development, 17(5), 1-6. Retrieved from ww.personales.ulpgc.es/aarguello.dpat/trabajos/trcon4.pdf

Cheeke, P. R. (1986). Potential of Rabbit Production in tropical and subtropical Agriculture system. Journal of Animal Science, 63, 1581-1586.

Dairo, F. A. S., Aina, O. O., \& Asata, A. R. (2005). Performance evaluation of growing rabbits fed varying levels of rumen content and blood-rumen content mixture. Nigerian Journal Animal Production, 32(1), 67-72.

Egbo, M. I., Doma, U. D., \& Landaks, A. B. (2001). Characteristics of small scale rabbit production and management in Bauchi metropolis. Proceedings of the $26^{\text {th }}$ annual conference of Nigeria Society for Animal Production (NSAP) (pp. 160-162).

Obi, I. U. (1990). Statistical methods of detecting differences between treatment means (2th ed.). Enugu, Nigeria: Snaap Press.

Oke, D. B., Adeyemi, O. A., Oke, M. O., \& Akinpelu, M. I. (2007). Utilization of Cirtus Waste in Broiler Diets. In Proceedings of the Annual Conference of Nigerian Soc. for Animal Production, 32, 168-218.

Oluokun, J. A., \& Olalokun, E. A. (1999). The effect of graded levels of broiler spent grains and kolanut pod meal on the performance characteristics and carcass quality of rabbits. Nigerian Journal of Animal Production, 26, 71-77. Retrieved from http//www.insap.info/ajol

Olupong, J. A., \& Balogun, O. O. (2005). Protein and energy values of some abattoir by-products for rabbits. Tropical Journal of Animal Science, 8(1), 33-37.

Oluremi, O. I. A., Ojighen, V. O., \& Ejembi, E. H. (2006). The nutritive potential of sweet orange (Citrus sinensis) in broiler production. International poultry science, 5(7), 613-617. Retrieved from www.pjbs.org/ijps/ab586.htm

Oluremi, O. I., Ngi, A. J., \& Andrew, A. I. (2007). Phyto-nutrients in citrus fruit peel meal and nutritional implication for livestock production. Livestock research for rural development, 19(7), 1-5. Retrieved from www.pjbs.org/ijps/ab586.htm

Olurunsanya, B., Ayoola, M. A., Fayeye, T. R., Olagunju, T. A., \& Olorunsanya, E. O. (2007). Effects of replacing maize with sundried cassava waste meal on growth performance and carcass characteristics of meat type rabbits. Livestock Research for Rural Development, 19(4), 20-27. Retrieved from www.lrrd.org/lrrd19/4/olor19055.htm

Omage, J. J., Onimisi, J. J., \& Agunbiade, M. O. (2007). The effect of Ginger (Zingiber officianale Roscoe) Waste meal on growth performance, carcass characteristics, serum lipid and serum cholesterol profiles of rabbit. Pakistan Journal of Nutrition, 6(4), 359-362. http://dx.doi.org/10.3923/pjn.2007.359.362

Tuleun, C. D., Njike, M. C., Ikurior, S. A., \& Ehiobu, N. G. (2005). Laying performances and egg quality of hens fed cassava root meal/brewer's yeast slurry based diets. Production Animal Techniques, 1, 148-152. Retrieved from www.pjbs.org/pjnonline/fin659.pdf

Udedibie, A. B. I, Anyaegbu, B. C., Onychekwu, G. C., \& Egbuokporo, O. C. (2004). Effect of feeding different levels of fermented and unfermented cassava tuber meals on the performance of broilers. Nigerian Journal of Animal Production, 31, 211-217.

Wardowski, W., Nagy, F. S., \& Grierson, N. (1986). Fresh Citrus Fruits. The Avi Publishing Co. West Port CT 571. Retrieved from www.aob.oxfordjournals.org/content/74/6/619.full.pdf 